DOI: 10.1515/linpo-2015-0005

\title{
From bodily posture to progressive aspect marker
}

\author{
Najib Ismail Jarad \\ University of Sharjah, njarad@sharjah.ac.ae
}

\begin{abstract}
Najib Ismail Jarad. From bodily posture to progressive aspect marker. The Poznan Society for the Advancement of Arts and Sciences, PL ISSN 0079-4740, pp. 89-111

The fact that posture verbs tend to grammaticalize into aspectual markers of progressivity in a widerange of (un)related languages makes them particularly interesting objects of study. The present paper aims to contribute to our understanding of how the active posture participle "yālis" (sitting) plus imperfective verb have come to express the progressive aspect in Emirati Arabic. The proposed answer to this puzzling question involves the claim that, crosslinguistically, progressive constructions are known to originate from locative constructions in which the agent is described as in the midst of an activity. The function of "yâlis" (sitting) as an auxiliary verb - like appears to be the result of a grammaticalization process, as certain principles of grammaticalization such as desemanticization, extension, and decategorialization were found to apply to it. Data from Emirati Arabic variety suggest that the construction has undergone semantic and morphosyntatctic changes but retained its phonetic content. As part of the new construction, the active participle "yālis" (sitting) has also changed its argument structure.
\end{abstract}

Keywords: grammaticalization, progressive aspect, posture verb, active participle, Emirati Arabic

\section{Introduction}

The Standard Arabic verb "jalasa" (literally 'he sat, stayed'), realized as "yilas" in Emirati Arabic, denotes one of three major human postures which are sitting, standing and lying. ${ }^{1}$ This verb belongs to a class of verbs known as cardinal posture verbs along with "qāma/ waqafa" (stand) and "iḍdaja“a/istalqa" (lie). According to Lichtenberk (2002: 273), verbs denoting "sitting, standing, and lying can be taken as the basic postures in the sense that they are the ones that languages are most likely to have simple lexemes for." The basic function of the three posture verbs (sit, stand, lie) is to describe the posture of the subject. In this way, the three verbs function semantically as stative rather than event verbs. Most languages have cardinal posture verbs but differ in the way they use these verbs. The difference has to do with whether the subject is animate or not, whether the verbs are stative, dynamic or both,

1 The Emirati Arabic equivalents to the Standard Arabic verbs "qāma/waqafa" (stand) and "idịaja'a/ 'istalqa" (lie) are "gām/wogaf" and "nsadah/nbațah", respectively. Note that the standard Arabic sound /j/ is realized as /y/ in Emirati Arabic. See Appendix 1 for the transcription symbols used in this paper. 
whether the verbs have only the posture meaning or additional extended lexical structures such as tense or aspect.

Emirati Arabic, a variety of Gulf Arabic which is used by Gulf Arabs from different Gulf States when they communicate with each other and with outsiders, is the variety of Arabic used in informal situations by the sedentary native people of the United Arab Emirates (Abu Dhabi, Dubai, Sharjah, Ajman, Umm al-Quwain, Ras al-Khaima, and Fujaira). It should be highlighted here that there is a high degree of mutual intelligibility among these Emirates; minor phonological and lexical differences do exist.

There are two constructions which express progressive aspect in Emirati Arabic: the active participle of a verb (1a) and the postural active participle "yālis" (sitting) plus the imperfective form of the verb (1b-e). ${ }^{2}$
'ali yālis fi l-kofi šob
Ali sitting in-the-coffee-shop
'Ali is sitting in the coffee shop'
b. 'ali yālis yi-gra yarīda
Ali PROG he-read newspaper
'Ali is reading a newspaper'
c. nūra yālsa ti-ktib risāla
Nora PROG she-write letter
'Nora is writing a letter'
d. 1-'ummāl yālsīn yi-tray-ūn l-bāṣs
The workers PROG they-wait the-bus
'The workers are waiting for the bus'
e. ummāya, ana ma yālsa a'ātbich ana yālsa atrajāch innich tsā' dī-ni Mother, I not PROG blame-you I PROG beg-you that-you-help-me 'Mother! I am not blaming you; I am begging you to help me'

The active participle in Arabic is a nominal form derived from a verb in predictable patterns and can function as either an adjective or a noun (Beeston 1970: 35). The active participle "yālis" in (1a) matches the finite active verb "yilas" (he sat). The active participle has been noted for its verbal characteristics due to the apparent tense or aspectual meanings it conveys. In spoken Arabic varieties the active participle is taken to be an important component of the tense/aspect systems. Holes (2004: 153) writes that “...participle development in the dialects has been different from that in written Arabic. Whereas in MSA the potential of the participles for noun coinage has been heavily exploited, in the dialects they have become an important element in verb syntax." Several researchers have described the different uses of the active participle in spoken Arabic varieties. For example, see Mitchell (1952), Al-Najjar (1991), Eisele (1999), Caubet (1991), Eksell (1985), Brustad (2000), Mughazy (2005), Kinberg (2001), and Eades \& Persson (2013). According to these scholars, the active participle expresses many temporal and aspectual values in different language contexts.

2 Other Gulf Arabic varieties use the pre-verbal particle $g \bar{a}$ ' $i d$, an active participle meaning 'sitting', as an independent aspectual particle indicating the progressivity of the action. Agius \& Harrak (1987) provide a survey of particles which are used to express the progressive aspect in South East Turkey, Iraq, Lebanon, Syria, Palestine, Egypt, Sudan, Tunisia, Morocco and Malta. 
According to Eades \& Persson (2013: 345), it is the context of the utterance combined with the lexical aspectual properties of the verb that result in an inferred aspectual/ temporal reading in any given instance of AP use rather than the active participle itself expressing all these aspectual and/or temporal values.

The posture participle "yālis" (sitting) is placed before an imperfective verb form of some verb types to form the most common progressive construction in EA. The participle "yālis" inflects according to the person, number, and gender of the subject noun phrase as illustrated in the examples above. In examples such as the above, the active participle "yālis" does not carry its regular lexical semantic meaning of "to sit" but rather has a grammatical function (i.e., it functions as a marker of progressive aspect). This kind of situation, where two homophonous words exist side by side, one functioning as a lexical category and the other as a grammatical one, is what has been described as 'divergence' by Hopper \& Traugott (2003: 114ff), or as 'functional split' by Heine \& Reh (1984: 57-59). This amounts to saying that grammaticalization of a form does not result in the elimination of old forms.

The discussion in the present paper will focus on (1b-d) and attempt to answer the main question of the paper: Why and how does the posture participle "yālis" (sitting) come to mark the progressive aspect in Emirati Arabic? The data for this study were collected from several sources: field work in Abu Dhabi, Fujaira, Ajman and Sharjah, personal communication with native speakers, television series, a grammaticality judgment questionnaire and interviews. ${ }^{3}$ Transcriptions of the material ignored the minimal phonological differences between the sedentary dialect areas of the United Arab Emirates. Instead, a unified representation of words was used to make it easier for readers who are not familiar with the phonological distinctiveness of each of the Emirati dialect areas to recognize words and read the examples provided. The syntactic analysis of these data pointed to the conclusion that the posture participle "yālis" (sitting) in Emirati Arabic has been partially grammaticalized into a progressive particle.

The paper investigates the grammaticalization of the progressive marker "yālis" (sitting) in Emirati Arabic from a synchronic perspective, accompanied with a preliminary analysis of its origin. Bybee et al. (1994: 3f) claimed that a diachronic approach makes it possible to actually explain linguistic theory. A diachronic approach also makes it possible to answer why a given construction has come to have a certain function. The study of Bybee et al. (1994: 23), for example, confirms that one sees similar paths of grammaticalization crosslinguistically. Generalizations about paths of development can be made, and through these, we can compare languages in a more efficient way. These crosslinguistic generalizations enable us to do research on historical developments even on languages where there are no early written records. It should be highlighted here that there are no historical records of Emirati Arabic (which is also the case of all spoken Arabic varieties); therefore, the reconstruction of the grammaticalization path of "yālis" ( sitting) cannot depend on historical evidence from the language. However, on the basis of the findings and generalizations of grammaticaliza-

I would like to express my sincere gratitude to the following native speakers for their help with the data: Nada Alhammadi, Noora Mohamed Alsahi Alzaabi, Amna I. Yousuf Almoosa Alnuaimi, Maitha K. Abdalla Ali Shuhail Alshuhail, Aisha A. Khalifa Ali Falah Alsuwaidi, Sumaiya A. Ahmed Almarzooqi, and last but not least Fatima M. Abdulla Ahli. 
tion theory and synchronic evidence from present-day Emirati Arabic, the paper will attempt to provide an explanation for the evolution of the progressive marker "yālis" (sitting).

The paper is structured as follows. In the next section, I examine the syntax and semantics of the lexical verb "yilas" (sat) in Emirati Arabic. In section 3, some concepts of grammaticalization will be discussed as they are represented in relevant theoretical works. In section 4, I will present an overview of progressive aspect, focusing on Veldler's aspectual classification of verbal predicates and its applicability to Emirati Arabic. In section 5, I will provide an explanation for the evolution of the progressive marker "yālis" (sitting) from the concrete bodily posture meaning to the abstract durative or progressive. Section 6 will conclude the paper.

\section{The lexical posture verb "yilas" in Emirati Arabic}

The use of posture verbs to describe human posture is considered the prototypical use of verbs like sit, stand, lie. Beyond their prototypical use, these verbs happen to be used in discourse in other constructions (see Newman 2002; Grinevald 2006 \& 2007). Lakoff \& Johnson (1980: 6) claim that part of "the human conceptual system is metaphorically structured and defined." This means that we tend to metaphorically conceptualize certain aspects of life in a systematic way. Posture verbs are claimed to be used to conceptualize the positions of entities surrounding us. In other words, people do not only use the posture verbs sit, stand, lie to denote their own posture, but they extend the concepts to the 'posture' of things other than themselves. This claim ties in with Lakoff \& Johnson's (1980: 7) observation that many conceptual metaphors "have a basis in our physical and cultural experience". Newman (2002: 7) considers the use of posture verbs to describe the location and spatial configuration of inanimate entities to be an extension of their central meaning, namely to describe human posture (see Schönefeld 2006 for a corpus-based analysis of English, German, and Russian posture verbs). Consider the following examples: ${ }^{4}$

(2) a. The encyclopedia sits on my shelf at home, gathering dust.

b. The court will sit tomorrow morning.

c. The house stood empty for years.

d. The national debt stands at fifty-five billion dollars.

e. Cambridge United are lying third in the league.

f. The river lies $30 \mathrm{~km}$ to the south.

A number of studies conducted on the behavior of posture verbs in various (un)related languages have shown that posture verbs have developed a range of different figurative meanings. The studies have also shown that in some languages posture verbs have developed some grammatical functions such as durativity or progressivity (Ebert 2000; Heine \& Kuteva 2002; Kuteva 1999 \& 2001; Lemmens 2002, 2004, 2005, \& 2006; Lemmens \& Perrez 2010; Newman 2001, 2002, \& 2009; Newman \& Rice 2004; Newman \& Yamaguchi 2002). While there exists a rich body of cross-linguistic research on posture verbs, there

4 These examples are extracted from Cambridge Advanced Learner 's Dictionary (3rd edition) on CD.ROM. 
is relatively little research that has been done on the variations in functions and behavior of posture verbs in the spoken varieties of Arabic. This paper is an attempt to contribute to our understanding of how the active posture participle "yālis" (sitting) plus imperfective verb have come to express the progressive aspect in Emirati Arabic.

Judging from the data collected, the verb "yilas" is used as a main verb to describe the spatial configuration of humans and animals, as in the following examples:

(3) a. tfažal '̄ilis 'ala 1-kirsi.

Please sit on the chair.

(Imperative)

b. '̄illis jiddām!

sit in front.

$\begin{array}{llll}\text { (4) a. } & \text { dašš } & \text { l-maylis } & \text { w-yilas hdāal š-šeih̆ } \\ & \text { entered-he } & \text { the-sitting room } & \text { and-sat next to the-Sheikh }\end{array}$

'He entered the sitting room and sat next to the Sheikh'

b. yilas 'ala l-kanaba w-ḡifa.

sat on-the-sofa and-dozed

'He sat on the sofa and dozed off'

(5) a. huwwa yālis hnāk b-rūḥa

(Present)

$\mathrm{He} \quad$ sitting there by-himself

'He is sitting there alone'

b. d-diyāya yālsa 'ala l-baiz

The chicken sitting on the eggs.

'The chicken is sitting on the eggs'

In examples like those above, the verb "yilas" expresses the central spatial locative meaning. Newman (2002) and Lemmens (2002) suggest that the use of posture verbs to describe the location and sometimes spatial configuration of inanimate items is a metaphorical extension of the use of the same verb forms to describe animate posture. Data from Emirati Arabic do not support the view that posture verbs are used to describe inanimate entities in configurations which are similar to human and animal postures described by the same verb forms. For example, while speakers of English may, but generally prefer not to use the posture verbs in locative sentences, Emirati speakers do not use posture verbs in existential constructions or in constructions where the subject is inanimate:

(6) a. There's a book (sitting/lying) on the table
b. fi ktäb
(*yālis/minsidị )
there book (sitting/lying)
'at-țāwli
l-lamba (*yālsa/minsidḥa) 'aț-țāwli
c. lamba (*yālsa/minsidha)
the-lamp (sitting/lying)
on-the-table
on-the-table

The ungrammatical sentences in $(6 \mathrm{~b}, \mathrm{c})$ can be converted into a grammatical one by removing the posture verb from the sentence. It should be highlighted that the verb "yilas" is formally an intransitive verb and has the following argument structure:

yilas $\quad(\mathrm{x}, \mathrm{y})$, where $\mathrm{x}=$ THEME and $\mathrm{y}=$ LOCATION 
It should also be highlighted that the locative PP can be optional, as in (8a) from Emirati Arabic and (8b) from English: ${ }^{5}$
a.
'omar yālis (fi 1-maylis)
b-rūha
Omar sitting (in the-living room) by-himself
'Omar is sitting (in the living room) alone'
b. Yvonne stood alone (in the hallway) for six hours
(Levin \& Rappaport Hovav 1995: 127)

To summarize, we can say that the posture verb "yilas" can be used to encode the spatial position of animate entities, but not that of inanimate entities. However, the verb has developed a secondary meaning (i.e., the aspectual meaning). The development of "yālis" (sitting) into a marker of progressive aspect in Emirati Arabic appears to be the result of the grammaticalization process, as certain principles of grammaticalization such as desemanticization, extension, and decategorialization were found to apply to it. Next, I discuss some principles of grammaticalization.

\section{General remarks on grammaticalization}

This is not the place to go into too much theoretical detail; therefore, I limit myself to some general remarks taken from recent studies in this field. Grammaticalization is a process of linguistic change that was first introduced a century ago by Antoine Meillet in his 1912 article entitled "L'évolution des formes grammaticales." Grammaticalization became more popular as the central focus of studies of grammatical change in the last three decades of the 20th century. Since then, there has been extensive work on grammaticalization in languages world-wide, including many Indo-European languages, Semitic languages, Chinese, Japanese, and Korean (see Heine \& Narrog 2011). According to Fischer et al. (2000: $1)$, grammaticalization is "arguably the most widely discussed type of linguistic change," and Hancil \& Koenig (2014: 1) argues that "theories and studies of grammaticalization have been a major source of inspiration for recent studies of language change." The term 'grammaticalization' is used in this paper to refer to the process whereby lexical items and constructions serve grammatical functions in certain linguistic contexts and, once grammaticalized, continue to develop new grammatical functions (see Kuryłowicz 1965: 52; Hopper \& Traugott, 2003: xv; Heine 2003: 575; Heine \& Kuteva 2002: 2; Heine \& Kuteva 2007: 32; Bybee 2010: 30, 106; Lehmann 2004: 155; Heine \& Narrog 2011: 2f; Traugott \& Dasher 2002: 81; Traugott \& Trousdale 2010: 2ff; Traugott \& Trousdale 2013: 94ff; Hancil \& Koenig 2014: 2ff; Smith et al. 2015: 2ff). According to those scholars, the new grammatical function of a linguistic expression does not arise homogeneously in all uses of the linguistic item concerned, but its origin is bound to specific linguistic contexts. In this respect, Bybee et al. (1994: 11) state that "it is the entire construction, and not simply the lexical meaning

5 However, when the English posture verbs are used with inanimate objects, the locative phrase is obligatory (Levin \& Rappaport Hovav 1995: 127)

a. The statue stood *(in the corner).

b. The purse lay*(on the table). 
of the stem, which is the precursor, and hence the source, of the grammatical meaning." (See Traugott 2005: 645). In the same vein, Lehmann (1992: 406) theorizes that 'grammaticalization does not merely seize a word or morpheme ... but the whole construction formed by the syntagmatic relations of the elements in question' (see Traugott \& Trousdale 2013: 94ff).

According to grammaticalization theorists, grammatical change is driven by changes in meaning and is unidirectional. Heine \& Kuteva (2005: 108) observe that "Grammaticalization is essentially unidirectional: At least 90 percent of all instances of grammatical change can be assumed to be in accordance with principles of grammaticalization." For example, Heine \& Kuteva (2005: 8) argue that it is common in many languages that the motion verb "to go" is grammaticalized into a future marker. However, to date, the case that a future tense marker is changed into the lexical item "to go" is not found in any language. Bybee et al. (1994: 13) argue that "The crosslinguistic consistency of such results encourages us to see the creation of grammatical material as evolution of substance from the more specific to the more general and abstract." Heine \& Kuteva (2005: 17) conclude that "more recent research has shown that there are some examples contradicting the unidirectionality hypothesis; however ... such examples are few, accounting for less than one tenth of all cases of grammatical change."

\subsection{Mechanisms and principles of grammaticalization}

In general terms, grammaticalization is both a diachronic and synchronic phenomenon whereby linguistic items are recategorized, for instance from nouns into prepositions, from verbs into auxiliaries, from adverbs into discourse markers, etc. The process of grammaticalization combines a number of certain principles and mechanisms of language change. There are four main interrelated principles of grammaticalization, namely, desemanticization, extension, decategorialization, and erosion. These principles can be considered as universally involved in the development of grammatical forms, as has been attested by studies on a wide range of languages (Bybee et al. 1994; Hopper \& Traugott 2003; Hopper 1991 \& 1996; Heine 2003: 579; Heine \& Kuteva 2002: 2ff; Heine \& Kuteva 2005: 15; Heine \& Kuteva 2006: 43ff; and Heine \& Kuteva 2007: 33ff). The four grammaticalization principles embrace the components of grammar in the following way: desemanticization relates to semantics, extension to pragmatics, decategorialization to morphosyntax and erosion to phonetics.

We will start with the principles that are relevant to our analysis of the posture verb. First, desemanticization or bleaching is understood as semantic reduction or loss in meaning content. In other words, what normally occurs is a move from a more lexical to more a grammatical meaning. Since grammatical units refer to very abstract concepts, such as temporal relations (past, future) or case relations (possession, goal), the items to denote these concepts must acquire a very general meaning. The principle of extension, or context generalization, refers to the use of a linguistic item in new contexts where it could not

6 The question of unidirectionality attracted a lot of criticism (see especially Newmeyer 1998 \& 2001; Haspelmath 1999 \& 2004; Fischer et al. 2004; Campbell 2001; Campbell \& Janda 2001; Janda 2001; Norde 2001 $\&$ 2009). Although some instances of change in the opposite direction, viz. from abstract to concrete have been identified (e.g. Ramat 1992), such cases are far fewer than the numerous examples concerning the unidirectionality hypothesis (Newmeyer 1998: 275-276; Haspelmath 1999 \& 2004). 
be used previously. The principle of decategorialization pertains to the fact that as a unit grammaticalizes, it loses its categorial properties prototypical of the lexical category it was formerly a member of. For example, when nouns are reanalyzed as determiners, they lose inherent descriptive content; when verbs are reanalyzed as auxiliaries, they lose argument structure.

Lastly, the principle of erosion refers to the loss of phonetic substance. When a lexical item splits into two uses, the lexical form retains its full phonetic form, whereas the grammaticalized item undergoes phonetic reduction. For example, in the process of grammaticalization of the future marker: going to > gonna. According to Heine \& Kuteva (2007: 42), phonological erosion is 'usually the last to apply in grammaticalization processes, and it is not a requirement for grammaticalization to happen.' In other words, phonetic reduction is neither a necessary nor a sufficient property of grammaticalization. As we are going to see later, the posture verb "yālis" (sitting) has evolved into a progressive aspect marker but has retained its phonetic form.

Crosslinguistically, posture verbs often grammaticalize into markers of aspect such as durativity or progressivity (Bybee \& Dahl 1989: 57-58; Bybee et al. 1994; Austin 1998; Ebert 2000; Kuteva 2001; Heine \& Kuteva 2002; Kuteva 1999 \& 2001). According to Bybee et al. (1994: 129)

The majority of progressive forms in our database derive from expressions involving locative elements... The locative notion may be expressed either in the verbal auxiliary employed or in the use of postpositions or prepositions indicating location... The verbal auxiliary may derive from a specific postural verb, such as 'sit', 'stand', or 'lie' or it may express the notion of being in a location without reference to a specific posture but meaning only 'be at', 'stay', or, more specifically, 'live' or 'reside'.?

What this means is that it is quite common for verbs that carry posture meanings to also be used with grammatical functions. That is, they mark some kind of aspect, the most common being durative or progressive. The following are a few examples from different languages:

(9) a.

Manhartha

(Austin 1998: 24)

$\begin{array}{llll}\text { Ngatha } & \text { kumpa-artu } & \text { tharla-rnu } & \text { papa-jaka. } \\ \text { 1SG.NOM } & \text { sit-USIT } & \text { feed-IMPF.SS } & \text { water-COM }\end{array}$

'I used to feed (him) with water.'

b. Swedish

(Platzack 1979: 55)

Linda sitter och röker på expeditionen.

Linda sits and smokes on office.the

'Linda is smoking in the office.'

c. Icelandic

(Jóhannsdóttir 2007: 361)

María situr og les

Mary sits and reads

'Mary is reading'

d. Norwegian

(Norwegian Bokmål; Haugen 1982: 158)

There is ample crosslinguistic evidence that supports the view that progressive markers originate from locative constructions (e.g., Comrie 1976: 98-103; Torres Cacoullos 2000: 121; Heine et al. 1991b; Heine 2003: 594). For example, Heine et al. (1991a) found more than a hundred African languages which had progressives based on locative sources, and Bybee et al. (1994: 128-129) also provide numerous examples from languages of diverse types. 
Vi satt og pratet.

we sit PAST and chat PAST

'We were chatting.'

e. Dutch

(Lemmens 2005)

Ik zat te lezen

I sat to read-INF

'I was (sitting and) reading'

In (9a) we have an example from the native Australian language Manhartha in which the verb kumpa, which generally has the meaning 'sit, camp, stay, live, be', is used to mark the continuous aspect (Austin 1998: 24). Additionally, what we have in (9b, c, d) is the Swedish, Icelandic, or Danish verb 'sit' functioning as a progressive aspect marker. Note that using a posture-verb coordination like $(9 b, c, d)$ is a very common way of forming the progressive in the Scandinavian languages. According to Tonne (2007), a structure like $(9 \mathrm{~b}, \mathrm{c}, \mathrm{d})$ is either called "a pseudocoordination" or a "postural verb construction" in which two (or more) verbs in the same tense (or lack of tense) are used. In this construction, the first verb describes a state or movement and functions in the discourse as a background for the action (or state) described by the next verb. Before considering the development of "yālis" into a progressive aspect marker, let us take a look at the term progressive aspect.

\section{An overview of progressive aspect}

It is a well-noted typological observation that in languages without a morphologically distinct progressive aspect, the imperfective aspect realizes the communicative function of the progressive aspect. The imperfective form of a verb in Modern Standard Arabic may license both progressive (10a) and habitual interpretations (10b) with non-stative predicates. The imperfective form also occurs with a lexical stative predicate as in (10c). Examples and transcription are from Ryding (2005: 442).

\begin{tabular}{|c|c|}
\hline & $\begin{array}{l}\text { ya-jlisu Salaa l-maqSad-i } \\
\text { sit-impf.3.m.sg on the seat } \\
\text { 'He is sitting on the seat' }\end{array}$ \\
\hline b. & $\begin{array}{l}\text { ya-Smalu fii l-Pidaarat-i } \\
\text { work-impf.3.m.sg in the administration } \\
\text { 'He works in the administration' }\end{array}$ \\
\hline c. & $\begin{array}{l}\text { ta-xtalifu } \quad \text { San ghayr-i-haa } \\
\text { differ-impf.3.f.sg from others } \\
\text { 'She differs from others' }\end{array}$ \\
\hline
\end{tabular}

Aspect is a universal semantic category dealing with "viewing the internal temporal constituency of a situation" (Comrie 1976: 3). Aspect is concerned with description of the temporal distribution of an event (activity, process, or state) in terms of its completion, inception, repetition, duration, etc. Although progressive aspect is a universal concept, languages differ in the way they express it. It is not necessary for progressive aspect to be 
overtly morphologically marked. Dahl (1985) reports that few languages have the durativity/progressivity category. Many others do not code durativity/progressivity on the verb, but have lexical entities expressing the semantic notion of durativity/progressivity. Like other contemporary spoken varieties of Arabic, Emirati Arabic has developed preverbal markers which can be added to the P-stem [Prefixed stem] to make finer aspectual and temporal distinctions.

Aspectual classifications group verbs or verbal predicates together based on sharing the same aspectual viewpoint and internal event structure. There are two types of aspect: grammatical and lexical. While grammatical aspect stands for the morphosyntactic marking of aspectual categories, lexical aspect is a semantic category that refers to the temporal characteristics of verbs and verbal predicates' meanings (Filip 2012: 721). ${ }^{8}$ Lexical aspect is also known as situation aspect or Aktionsart 'kind of action' (Smith 1997: 3). Bybee et al. (1994: 55) refer to lexical aspect as situation, using a term also applied by Smith (1997) as opposed to grammatical aspect. In most cases, the term refers to the aspectual distinctions defined by the lexical character of the verb itself, rather than any grammatical morphology that is associated with the predicate as a whole. With respect to grammatical aspect, there are two major categories: perfective and imperfective (Comrie 1976). Comrie describes the difference between the two aspects in such a way that the perfective looks at the situation from outside but the imperfective from inside. Smith (1983: 479) says that the "sentential aspect represents the speaker's choice of perspective on the situation".

Comrie (1976: 24) defines imperfective aspect as an "explicit reference to the internal temporal structure of a situation, viewing a situation from within." In other words, imperfective aspect presents a situation from an internal point of view, often as ongoing (progressive) or enduring (continuous), whereas perfective aspect presents a situation from an external perspective, often as completed. As it is the progressive aspect that is the focus of this paper, we will not further discuss the perfective aspect but turn to the progressive/ imperfective.

For lexical aspect, the best known categorization of verbs is that of Vendler (1967: 97121). Vendler divided verb phrases or verbal predicates into four classes according to their time schema (see e.g. Dowty 1979; Binnick 1991: 172; Smith 1997; Rothstein 2004; Van Valin 2006; Croft 2012: 33-45). In this model, stative predicates "are static, with no dynamic and no internal structure; they have duration of at least a moment" (Smith 1997: 28). Activity predicates consist of successive phases with one following the other over time. They have no set terminal point or endpoint; the processes are ongoing in time and should be identical and homogeneous. Accomplishment predicates are durative events that are telic, or have a natural endpoint. ${ }^{10}$ Unlike activity predicates, accomplishment predicates are not identical and homogenous. The action of an accomplishment verb refers to the whole time segment, not just one point of the segment. Achievement predicates are "instantaneous changes of

8 Grammatical aspect is also known as verbal aspect or viewpoint aspect (Smith 1997: 61), a wide-spread grammatical category, but may not exist in all languages (Dahl 2001).

9 However, Klein (1994) argued that these explanations of aspect are not particularly precise, and it can be hard to see whether the speaker is referring to a situation from the inside or from the outside. For more on this counter argument, see Klein (1994: 29).

${ }^{10}$ An event with an inherent limit or endpoint is called telic (from Greek telos 'limit, end, goal') and an event without such a limit is called atelic. 
state, with an outcome of a new state" (Smith 1997: 28). ${ }^{11}$ There is not universal agreement regarding these classes and how they are defined. Nonetheless, for our purposes, those given here will suffice as a point of reference for this general discussion of aspectual composition.

Verbal predicates fall into one of these four classes based on whether or not they are associated with the features of \pm Telic, \pm Durative and \pm Dynamic (Smith 1997: 3). The table below illustrates this classification with examples and the three defining features.

Table 1: Vendler's aspectual classes

\begin{tabular}{|c|c|c|c|c|}
\hline \multirow[t]{2}{*}{ Aspectual class } & \multirow[t]{2}{*}{ Verb phrase } & \multicolumn{3}{|c|}{ Temporal Features of Verb Phrases } \\
\hline & & Telic & Durative & Dynamic \\
\hline Statives & $\begin{array}{l}\text { be happy, desire, want, love, hate, } \\
\text { know/believe, intend, fear, etc. }\end{array}$ & - & + & - \\
\hline Activities & $\begin{array}{l}\text { run, walk, swim, push a cart, drive } \\
\text { a car, etc. }\end{array}$ & - & + & + \\
\hline Accomplishments & $\begin{array}{l}\text { run a mile, walk to school, paint a pic- } \\
\text { ture, grow up, deliver a sermon, re- } \\
\text { cover from illness, build a house, etc. }\end{array}$ & + & + & + \\
\hline Achievements & $\begin{array}{l}\text { recognize, find, lose, win the race, } \\
\text { stop/start/resume, be born/die, etc. }\end{array}$ & + & - & + \\
\hline
\end{tabular}

According to the table above, statives are not dynamic, and are atelic and durative; activities are dynamic and have duration and no inherent endpoint. Whereas achievements are dynamic and telic and are perceived as instantaneous, accomplishments are dynamic, durative, and telic, and consist of process and outcome. Consider the examples below:

States

a. Bill loves his cat.

b. Mary knows the answer.

$$
\text { Activities }
$$

a. John is playing table tennis.

b. Jane is eating fish and chips.

$$
\text { Accomplishments }
$$

a. Mary is drawing a picture.

b. Ian is carving a bird.

$$
\text { Achievement }
$$

a. The contestants reach the summit.

b. John won the race.

Although Vendler's verb phrase classification is a useful tool for aspectual classification, it is not without problems (see Croft 2012: 33-45). For example, the classification of a verb as belonging to one class is not entirely accurate especially when other words in the sentence (nominal arguments, PPs, adverbials, particles) can force the same verb to denote

11 Smith (1997: 28-30) extends Vendler"s classes to include semelfactives (from the Latin semel meaning 'once'), which are single actions presented as punctual, hence [+dynamic] but not [+durative] and with no built-in resulting endpoint. For example, "Mary sneezed, burped, winked, blinked, etc." or "John knocked at the door; John hammered the nail; John slapped Bill" are typical examples of semelfactive events. 
different situation types. For example, a prototypical achievement verb such as sit may have the following uses: ${ }^{12}$

$\begin{array}{ll}\text { State: } & \text { Their decision/answer didn't sit well with the Board of Di- } \\ & \text { rectors (to be something that you agree or are pleased with) } \\ \text { Activity: } & \text { The court will sit tomorrow morning (hold an official meet- } \\ & \text { ing) } \\ \text { Accomplishment: } & \text { After I've sat my exams, I'm going on holiday (take an ex- } \\ & \text { amination) } \\ \text { Achievement: } & \text { He came and sat (down) next to me. }\end{array}$

The predicate type and the inherent temporal properties of the lexical content in an utterance play a significant role in the use and meaning of the progressive form. Activities and accomplishments constitute the prototype verbs for the use of the progressive. Achievement verbs do not occur in the progressive form because their temporal schema has no interval, and consequently, they have no structure of successive stages. However, the progressive can be used with achievements when the focus is on the preliminary stages of the event with no information as to its outcome (Smith 1997: 75):

(16) a. The team was reaching the top

b. She was winning the race

Statives do not generally occur in the progressive. They have neither an internal structure nor a well-defined endpoint. Moreover, states are completely homogeneous in that every point of a state is identical to every other point. This means that every part of the stative is identical to every other part, including the entire state. However, the progressive has an internal structure of successive stages, and the interval focused by the progressive is a process. A process is [+dynamic], whereas a state is [-dynamic]. Therefore, stative verbs are generally resistant to progressive aspect. ${ }^{13}$ For example,

(17) a. John owns two expensive cars.

b. *John is owning two expensive cars

To sum up, activities and accomplishments are quite natural and consistent with the inherent features of the progressive, whereas achievements and statives are to a large extent incompatible with the progressive. This conclusion accords with the universal aspectual values underlying Vendler's four-way classification of aspectual classes of verb phrases.

Having briefly outlined the basic classification of Vendler's scheme, we may now investigate its applicability to Emirati Arabic. Emirati Arabic verbs are said to behave in much the same way as their English counterparts. Consider the following examples where the participle "yālis" (sitting) is used with action verbs denoting activity in the present (18) and in the past (19).

12 These examples are extracted from Cambridge Advanced Learner 's Dictionary (3rd edition) on CD.ROM.

${ }^{13}$ However, there are some exceptions. For example, think is a stative verb which denotes a mental state; therefore, in "I think I have met you before", think occurs in the form of 'simple present'. However, it can also occur in the progressive aspectual form, as in "I am thinking of renting a new flat." In this example, the progressive aspect no longer denotes a mental state but a kind of planning or solving a problem. This means that the progressive aspect has changed the situation from static to dynamic (see Huddleston \& Pullum 2002: 170). 
(18)
nūra yālsa
ti-gašir
bṭāt
fi-l-mațbah
Nora PROG
she-peel potatoes
in-the-kitchen

'Nora is peeling potatoes in the kitchen'
b. 'afra yālsa ti-ḡanni fi-l-ḥammām
Afra PROG she-sing in-the-bathroom
'Afra is singing in the bathroom'

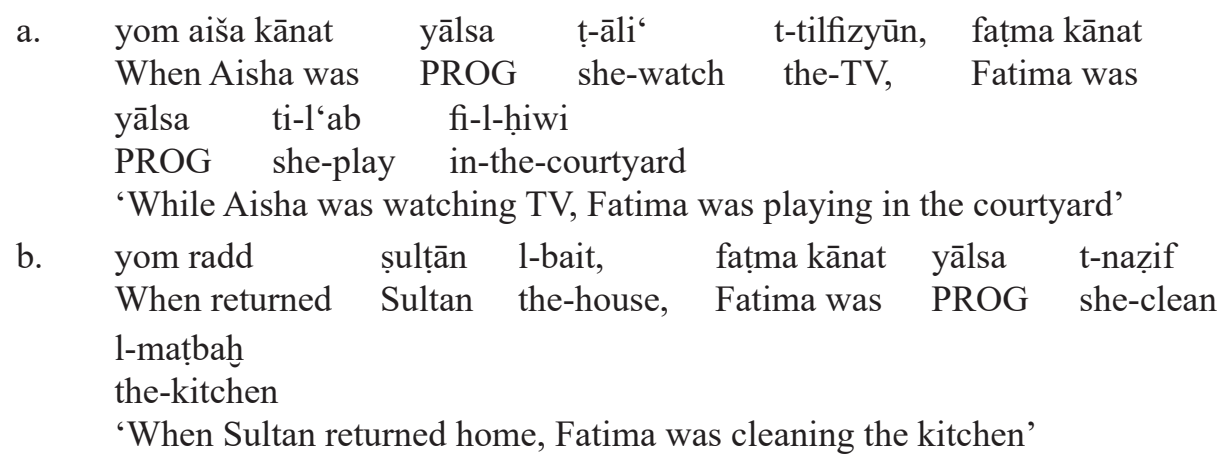

In (18), the progressive describes a durative incomplete action in progress whereas in (19) the progressive indicates the relative duration of one action to another action which took place while the first was in progress.

Accomplishment predicates are treated the same as activity predicates. Accomplishments are conceived of as processes which come to a conclusion. The following are examples of accomplishment verbs:
sāra yālsa ti-ktib imail ḥagg-rab'a Sara PROG she-write email to friends-her. 'Sara is writing an email to her friends'
b. 1-banšar-ji yālis yi-ṣallị̣ t-twāyir the-puncture-man PROG he-repair the-tires 'The tire repairman is repairing the tires'

Like achievement predicates, accomplishment predicates in Arabic have inherent endpoints, and are therefore [telic], but they are different in that accomplishments are durative. Moreover, both achievements and accomplishments in Emirati Arabic are compatible with past tense and progressive markings.

(21) a. fațma kānat yālsa ti-ḡsil wayy-ha yawm ngaț it 1-māyy

Fatima was PROG she-wash face-her when stopped the-water

'Fatima was washing her face when water ran out'

b. yirāna kānow yālsīn yi-trayg-ūn yom šabbat 1-ḥarīja neighbors-our were PROG they-breakfast when started the fire fi-l-mațbah in the kitchen

'Our neighbors were having breakfast when the fire broke out in the kitchen' 

c. wildi yālis yi-rsim șūrat sūg s-simach.
son-my PROG he-draw picture market the-fish
'My son is drawing a picture of the fish market'
d. yālis yi-bni 'māra fi šāri' š-šeih ḥamdān
PRO he-build building in street Sheikh Hamdan
'He is building a building on Sheikh Hamdan Street'

Stative verbs refer to states rather than actions. They manifest grammatical traits that are different from those of non-stative verbs in Emirati Arabic. Verbs associated with cognition, emotion, and attitude constitute an important class of stative verbs: yit'assaf (regret), yidakkar (remember), yifham (understand), yagșid (intend), yibḡa/yiba (want) yāmin (believe), yiwäfig (agree), yih̄âf (fear), yinsā (forget), yāmmal (hope), yihsid (envy), yikrah (hate), yihibb (love), etc. These stative verbs do not generally occur with the progressive construction yālis + imperfective verb because they lack stages, which are essential characteristics of events and not of states. ${ }^{14}$ To determine if the structure 'yālis'+ imperfective verb is restricted in stative sentences, I conducted grammaticality judgment experiments with native speakers. The following examples demonstrate the ungrammaticality of stative verbs with yālis + imperfective verb:
*'omar yālis yi-krah maryam Omar PROG he-hate Mariam
b. *maryam yālsa ta-'arf leiš 'omar yālis yi-krah-a Mariam PROG she-know why Omar PROG he-hate-her
c. *maryam yālsa ti-ḥsid fațma 'ala sayyārta l-yidīda Mariam PROG she-envy Fatima on car-her the-new
d. *l-‘yāl yālsīn yi-ḥib-ūn 1-chaklait
The kids PROG they-love the chocolate

The idea is then that verbs that occur in the progressive are events but those that cannot are stative verbs; hence, the ungrammaticality of the above examples is accounted for. Note that the above stative verbs cannot also be used in the imperative (see Lakoff 1970: 121; Dowty 1979: 55):
a. $\quad$ *ikrah maryam Hate Mariam
b. *i'rif laiš 'omar yālis yi-krah maryam Know why Omar PROG he-hate Mariam

\footnotetext{
${ }_{14}$ According to Huddleston \& Pullum (2002: 170), the English equivalents of the Emirati Arabic stative verbs above do not completely exclude the progressive, but they differ with respect to how easily they take it. In the same vein, Bach (1981: 77) observes that most stative predicates can be used with special interpretations in the progressive, as in:

a. I'm really loving the play.

b. I'm understanding you but I'm not believing you.

The acceptability of progressive sentences with stative predicates seems to depend on whether the stative verb can be coerced into expressing a contingent property that changes over time. In other words, when the stative verb is coerced into being eventive, it behaves like an activity and the progressive becomes available.
} 


$\begin{array}{ll}\text { c. } & \text { Eḥsid fațma 'ala sayyārta l-yidīda } \\ \text { Envy Fatima on } & \begin{array}{l}\text { car-her the-new } \\ \text { *hibb l-chaklait } \\ \text { love the-chocolate }\end{array}\end{array}$

Examples (23) show that imperative forms are impossible with those stative verbs. The ungrammaticality of the above examples stems from the fact that the imperative mood expresses direct commands or requests. We usually command someone to do something.

Another test provided by Lakoff (1970: 121) and Dowty (1979: 55) has to do with the impossibility of stative verbs occurring as complements of verbs like 'force' and 'persuade':

(24) a. *John persuaded/forced Barry to know the answer.

b. John persuaded Harry to run.

c. John forced Harry to build a house.
*'omar agnna' maryam ti-ḥsid faṭma 'ala sayyārta l-yidīda. Omar persuaded Mariam she-envy Fatima on car-her the-new 'Omar persuaded Mariam to envy Fatima her new car'
b. *Maryam ḡṣabit 1-'yāl yi-ḥibb-ūn 1-chaklait Mariam forced the-kids they-love the chocolate 'Mariam forced the kids to love the chocolate'
c. ganna'ni asāfir bu zabi wiyyā. persuade-me travel Abu Dhabi with-him 'He persuaded me to travel to Abu Dhabi with him'
d. gișabha tāhid wild 'ammaha. forced-her take son uncle-her 'He forced her to marry her cousin'

Sentences $(25 \mathrm{a}, \mathrm{b})$ are impossible because the person who persuades or forces someone else to do something usually needs to have control over the situation as it is impossible to persuade or force someone to do something (i.e. to envy someone or to love something). Having looked at Vendler's aspectual classification and its applicability to Emirati Arabic, I turn now to the development of the posture verb "yālis" (sitting) into a marker of progressive aspect.

\section{The aspectual extension of the posture verb "yilas"}

The aspectual extension of the posture verbs 'sit', 'stand' and 'lie' into markers of progressive aspect is a cross-linguistically frequently attested phenomenon (Bybee et al. 1994; Heine \& Kuteva 2002; Kuteva 1999 \& 2001; Lemmens 2002, 2004, 2005, \& 2006; Lemmens \& Perrez 2010; Newman 2001, 2002, \& 2009; Newman \& Rice 2004; Newman $\&$ Yamaguchi 2002). With regard to the aspectual meaning, Comrie (1976: 11) points out that "...the existence of both basic and secondary meanings can be shown to be the result of a historical process where the basic meaning is the original meaning, while secondary meanings have been acquired as extensions of this original meaning." The active participle "yālis" (sitting) is used in constructions where it seems to be bleached of all its lexical 
meaning, and the syntactically dependent verb expresses the primary predicate semantics. It should be highlighted here that the participle "yālis" (sitting) cannot be used with all types of verbs. Action verbs such as those indicating activity and accomplishment occur in this progressive construction more frequently than other verb types. The following examples illustrate the use of "yālis" plus an action verb in the present:
hamad yālis yi-ḡanni w- yi-ḥlim bi hurm-ta
Hamad PROG he-sing and he-dream in woman-his
'Hamad is singing and dreaming of his (future) partner'
b. fațima yālsa ti-tgahwa țūl 1-yawm
Fatima PROG she-drink-coffee long the-day
'Fatima has been drinking coffee all day'
$\begin{array}{llll}\text { c. moza yālsa } & \text { ti-l'ab } & \text { wiyya } & \text { ribī'a-ta } \\ \text { Moza PROG } & \text { she-play } & \text { with } & \text { friend-her }\end{array}$
'Mosa is playing with her friend'
d. moza yālsa țāliৎ t-tilfizyūn w tirmis fi-1-mubāyil
Moza PROG watch the-television and talk with-the-mobile
'Moza is watching television and talking on the phone'

In the above examples the progressive describes a durative incomplete action in progress. Now consider the following examples with "yālis" plus an action verb in the past:
kint yālis i-dris yom 'omar farr l-ḥașa 'a- d-drīša was-I PROG I-study when Omar threw the-stone on the-window 'I was studying when Omar threw the stone against the window'
b. yom radd șultān 1-bait, nūra kānat yālsa ti-dris
'When Sultan came home, Nora was studying'
When returned Sultan the house, Nora was-she PROG she-study

Here, the progressive indicates the relative duration of one action to another which took place while the first was in progress. In (27a), I was studying before and after Omar threw the stone at the window, and in (27b) Nora was studying when Sultan came home. Next, consider the use of "yālis" plus an action verb in the future:

28) a. bāchir mitil hal wagt fatma bi-tkūn yālsa ti-dris fi-l-maktaba

Tomorrow like this time Fatima will-be PROG she-study in-the-library

'Tomorrow this is time Fatima will be studying in the library'

b. 1-isbū' il-yāy mitil hal wagt real madrīd

The-week the-coming like this time Real Madrid

bi-kūn yālis yil'ab l-final.

will-be PROG play the-final

'Next week this time Real Madrid will be playing in the final'

In all the examples above, the active participle "yālis" (sitting) has an auxiliary verb -like function. These examples involve extension in semantic content of the participle "yālis". In other words, the grammaticalization of "yālis" (sitting) involved the metaphori- 
cal extension of the original meaning from the cognitive domain of space (bodily posture sense) to the abstract domain of time ("yālis" as a progressive marker). According to Heine \& Kuteva (2002: 3; Heine \& Kuteva 2007: 35), extension must occur first, followed by the other mechanisms.

The extension of the meaning of the lexical participle verb "yālis" triggers desemanticization or semantic bleaching. Desemanticization is understood as semantic reduction or loss in meaning content and arises when lexical items with concrete meanings are reinterpreted in specific contexts as more abstract, grammatical meanings. What normally occurs is a move from a more lexical to more a grammatical meaning. Therefore, the more a linguistic item is grammaticalized, the more reduced its valency will be. From a synchronic point view, the active participle "yālis" does not display the same complementation pattern as the non-grammaticalized lexical verb does. In Emirati Arabic, the verb "yilas" is a two-place predicate which subcategorizes for an external NP and a locative PP <theme, ${ }_{\mathrm{PP}}$ Loc $>$ (see section ). When "yilas" is reanalyzed as a progressive marker "yālis", it is no longer compatible with any argument structure. In other words, the theta-roles of "yilas" are bleached out leaving only the relation of progressivity or durativity.

Grammaticalization requires specific contexts to take place. Therefore, the progressive reading in constructions like the above can be keyed to the fact that the participle "yālis" has actually been decategorialized into a progressive marker. The decategorialization of "yālis" does not emerge out of the verb taken in isolation, but rather out of the construction in which the verb is combined with some other linguistic item. More precisely, in the course of grammaticalization, the lexical structure main verb + complement evolves into the grammatical structure grammatical marker + main verb (see Heine 1993: 59-65).

When a lexical item splits into two uses, the lexical form retains its full phonetic content whereas the grammaticalized item undergoes phonetic reduction. In the case under discussion, although the verb "yilas" splits into two divergent uses, the grammaticalized form "yālis" retains its full phonetic content. This is not unusual since phonological change is not reliant on syntactic change. According to Heine \& Kuteva (2007: 42), phonological erosion is "usually the last to apply in grammaticalization processes, and it is not a requirement for grammaticalization to happen." In other words, phonetic reduction is neither a necessary nor a sufficient property of grammaticalization.

The question that arises here is how can posture verbs develop into markers of progressive aspect? With regard to the function of progressive aspect, Bybee et al. (1994: 133) point out that 'the original function of the progressive is to give the location of an agent as in the midst of an activity' (see Comrie 1976; Heine et al. 1991a \& 1991b; Bybee et al. 1994; Bybee 2010; Bybee \& Torres Cacoullos 2009; Kuteva 1999 \& 2001; Heine \& Kuteva 2002). At first, the construction is used with activities where a clear location is given. The following elements are then present in the constructions that later grammaticalize into progressives (see Bybee et al. 1994: 136):

(29) a. an agent (X)

b. $\quad \mathrm{X}$ sits in a $\mathrm{Y}$ manner (i.e., $\mathrm{X}$ is located spatially)

c. in the midst of

d. an activity

e. at reference time 
For example, if $\mathrm{X}$ is reading, $\mathrm{X}$ is regarded as being located in the midst of reading; ongoing activities are construed as locations in which agents find themselves in (e.g. She is in the middle of reading). Accordingly, Bybee et al. (1994: 127-137) suggest that location is a necessary semantic component of progressive aspect. Posture verbs denote bodily positions which the whole body is literally situated or locked in. For instance, in the location schema $\mathrm{X}$ sits or is located in a $\mathrm{Y}$ manner, $\mathrm{X}$ is construed to be located in a particular posture, just as, in the case of progressive aspect, an agent is construed to be located in the midst of an activity (Heine 1994: 269). The transfer from a bodily posture to a progressive construction can be explained as the result of a unidirectional transfer from the more concrete domain of space to the more abstract domain of verbal aspect. This conceptual similarity may be what motivates posture verbs to develop into progressive-aspect-bearing elements in many languages of the world. This development may thus involve a metaphorical process whereby the abstract meaning of progressive aspect is conceptualized in terms of the concrete meaning of bodily postures (e.g. Heine et al. 1991b).

The development from the concrete bodily posture (or locative) meaning to the abstract durative or progressive can be sketched as follows:

$$
\begin{array}{ll}
\text { Stage I: bodily posture (locativity) } & =\text { stative } \\
\text { Stage II: progressivity } & \text { residually locative, durative or pro- } \\
& \text { gressive }
\end{array}
$$

Locative constructions are said to express stative meaning. Bertinetto et al. (2000: 539) claim that 'locative' implies that the meaning of the progressive was originally that of "being (i.e., finding oneself/itself) in a state." In such constructions, the locative verb does not function as an auxiliary, but as a full lexical verb, which is followed by an independent non-verbal element (i.e., complement). What happens is that the main verb is reanalyzed and desemanticized into an auxiliary while the non-verbal element acquires the status of main verb. Stage (II) represents the initial stage of grammaticalization. Here the postural verb begins to develop into an auxiliary. In other words, the lexical structure main verb + complement evolves into the grammatical structure grammatical marker + main verb. The construction now expresses durative or progressive meaning, but this meaning co-exists with the older locative meaning. This kind of situation, where two homophonous words exist side by side, one functioning as a lexical category and the other as a grammatical one, is common in grammaticalization processes and has been described as 'divergence' by Hopper \& Traugott (2003: 114ff), or as 'functional split' by Heine \& Reh (1984: 57-59). This amounts to saying that grammaticalization of a form does not result in the elimination of old forms. In other words, the original lexical item remains in use as a full lexical item next to the grammaticalized one, each going their separate ways.

\section{Conclusion}

One of the vital insights of grammaticalization theory is that grammaticalization does not affect words in isolation but words in specific syntactic constructions. That is, the development of postural verbs into markers of progressive aspect takes place in constructions 
in which verb + complement develops into constructions of the type progressive marker + main verb. This insight is borne out by the evidence provided in this paper. This paper has shown that the posture verb "yālis" in Emirati Arabic can be used to encode the spatial position of animate objects but not that of inanimate objects. This is also found to be true of the other posture verbs "gām" (stand) and "nbațạ" (lie). The paper has also shown that the posture participle verb "yālis" in Emirati Arabic behaves like a progressive auxiliary. This situation is identified in Emirati Arabic, with "yālis" existing as a full lexical; at the same time we find a phonologically identical form which is used before another verb to impose a particular aspectual contour on the event coded by the second verb. The resulting interpretation is that the described event has an extended duration or is in progress, i.e., as durative or progressive. Consequently, what we find is a grammaticalized auxiliary-like form and an autonomous lexical verb existing side by side. While the participle is by no means fully grammaticalized, its auxiliary-like behavior in Emirati Arabic represents a distinct point on the grammaticalization cline of lexical postural verbs into grammatical markers of progressivity.

\section{Primary source}

Lie. [Def. 2]. 2008. Cambridge Advanced Learner's Dictionary. [CD ROM]. Produced for Cambridge University Press by Armada.

Sit. [Defs. 1,5,8,10]. 2008. Cambridge Advanced Learner's Dictionary. [CD ROM]. Produced for Cambridge University Press by Armada.

Stand. [Def. 2]. 2008. Cambridge Advanced Learner's Dictionary. [CD ROM]. Produced for Cambridge University Press by Armada.

\section{References}

Agius, Dionisius \& Harrak, Amir. 1987. Auxiliary Particles Preceding the Imperfective Aspect in Arabic Dialects. Arabica 34(2). 164-180.

Al-Najjar, Balkees. 1991. Grammaticalization of Lexical Markers in Kuwaiti Arabic. Folia Linguistica 25. 665674.

Austin, Peter. 1998. Crow is sitting chasing them: Grammaticalisation and the verb "to sit" in the Mantharta languages, Western Australia. In Siewierska, Anna \& Song, Jae Jung (eds.), Case, Typology and Grammar: in Honour of Barry J. Blake. Amsterdam: John Benjamins, 19-36.

Bach, Emmon. 1981. On time, tense and aspect: and essay in English metaphysics. In Cole, Peter (ed.), Radical Pragmatics, 63-81. New York: NY Academic Press.

Beeston Alfred Felix Landon. 1970. The Arabic Language Today. London: Hutchinson University Library.

Bertinetto, Pier Marco \& Ebert, Karen H. \& de Groot, Casper. 2000. The Progressive in Europe. In Dahl, Östen (ed.), Tense and Aspect in the Languages of Europe, 517-558. Berlin: Mouton de Gruyter.

Binnick, Robert. 1991. Time and the Verb: A Guide to Tense and Aspect. New York: Oxford University Press.

Brustad, Kristen. 2000. The Syntax of Spoken Arabic, Washington: Georgetown University Press.

Bybee, Joan. 2010. Language, Usage and Cognition. Cambridge: Cambridge University Press.

Bybee, Joan \& Dahl, Östen. 1989. The Creation of Tense and Aspect Systems in the Languages of the World. Studies in Language 13(1), 51-103.

Bybee, Joan, \& Torres Cacoullos, Rena. 2009. The role of prefabs in grammaticization: How the particular and the general interact in language change. In Corrigan, Roberta \& Moravcsik, Edith \& Ouali, Hamid, \& Wheatley Kathleen (eds.), Formulaic language, Vol. I, 187-217. Typological Studies in Language. Amsterdam-Philadelphia: John Benjamins. 
Bybee, Joan \& Perkins, Revere \& Pagliuca, William. 1994. The Evolution of Grammar. Tense, Aspect, and Modality in the Languages of the World. Chicago: University of Chicago Press.

Campbell, Lyle. 2001. What's Wrong with Grammaticalization? Language Sciences 23. 113-161.

Campbell, Lyle, \& Janda, Richard. 2001. Introduction: Conceptions of Grammaticalization and their Problems. Language Sciences 23. 93-112.

Caubet, Dominique. 1991. The Active Participle as a Means to Renew the Aspectual System: A Comparative Study in Several Dialects of Arabic. In Kaye, Alan S. (ed.), Semitic Studies, 207-224. Wiesbaden: Otto Harrassowitz.

Comrie, Bernard. 1976. Aspect: An Introduction to the Study of Verbal Aspect and Related Problems. Cambridge: Cambridge University Press.

Croft, William. 2012. Verbs: Aspect and Causal Structure. Oxford: Oxford University Press.

Dahl, Östen. 1985. Tense and Aspect Systems. Oxford: Blackwell.

Dahl, Östen. 2001. Languages without tense and aspect. In Ebert, Karen H. \& Zúñiga, Fernando (eds.), Aktionsart and Aspectotemporality in Non-European Languages, 159-172. Zürich: Universität Zürich, Seminar für Allgemeine Sprachwissenschaft.

Dowty, David R. 1979. Word Meaning and Montague Grammar. The Semantics of Verbs and Times in Generative Semantics and in Montague's PTQ. Dordrecht: Reidel.

Eades, Domenyk, \& Persson, Maria. 2013. Aktionsart, Word Form and Context: on the Use of the Active Participle in Gulf Arabic Dialects. Journal of Semitic Studies 58(2). 343-376.

Ebert, Karen H. 2000. Progressive markers in Germanic languages. In Dahl, Östen (ed.), Tense and aspect in the languages of Europe, 605-653. Berlin: Mouton de Gruyter.

Eisele, John Clese. 1999. Arabic Verbs in Time: Tense and Aspect in Cairene Arabic. (Semitica Viva 20. Wiesbaden).

Eksell, Kerstin. 1985. On the Function of the Verbal Active Participle in Northern Arabian Narrative Texts. Acta Orientalia 46. 7-22.

Filip, Hana. 2012. Lexical aspect. In Binnick, Robert I. (ed.), The Oxford Handbook of Tense and Aspect. Oxford: Oxford University Press.

Fischer, Olga \& Rosenbach, Anette \& Stein, Dieter (eds.). 2000. Pathways of change: grammaticalization in English. Amsterdam-Philadelphia: John Benjamins.

Fischer, Olga \& Norde, Muriel \& Perridon, Harry (eds.). 2004. Up and Down the Cline. The Nature of Grammaticalization. Amsterdam-Philadelphia: John Benjamins.

Grinevald, Colette. 2006. The expression of static location in a typological perspective. In Hickmann, Maya \& Stéphane, Robert (eds.), Space in Languages: Linguistic Systems and Cognitive Categories, 29-58. Amsterdam-Philadelphia: John Benjamins.

Grinevald, Colette. 2007. The Linguistic Categorization of Spatial Entities. Classifiers and other Nominal Classification Systems. In Aurnague, Michel \& Hickmann, Maya, \& Vieu, Laure (eds.), The Categorization of Spatial Entities in Language and Cognition, 93-121. Amsterdam: John Benjamins.

Hancil, Sylvie, \& Koenig, Ekkehard. 2014. Introduction. In Hancil, Sylvie \& Koenig, Ekkehard (eds.), Grammaticalization - Theory and Data. Amsterdam-Philadelphia: John Benjamins.

Haspelmath, Martin. 1999. Why is Grammaticalization Irreversible? Linguistics 37(6). 1043-1068.

Haspelmath, Martin. 2004. On Directionality in Language Change with Particular Reference to Grammaticalization. In Fischer, Olga \& Norde, Muriel \& Perridon, Harry (eds.), Up and Down the Cline: The Nature of Grammaticalization, 17-44. Amsterdam-Philadelphia: John Benjamins.

Haugen, Einar. 1982. Scandinavian Language Structures. A Comparative Historical Survey. Tübingen: Niemeyer. Heine, Bernd. 1993. Auxiliaries: Cognitive Forces and Grammaticalization. Oxford: Clarendon Press.

Heine, Bernd. 1994. Grammaticalization as an Explanatory Parameter. In Pagliuca, William (ed.), Perspectives on Grammaticalization, 255-287. Amsterdam-Philadelphia: Benjamins.

Heine, Bernd. 2003. Grammaticalization. In Joseph, Brian D. \& Janda, Richard D. (eds.), The Handbook of Historical Linguistics, 575-601. Oxford: Blackwell.

Heine, Bernd \& Kuteva, Tania. 2002. World Lexicon of Grammaticalization. Cambridge: Cambridge University Press.

Heine, Bernd \& Kuteva, Tania. 2005. Language Contact and Grammatical Change. New York: Cambridge University Press.

Heine, Bernd \& Kuteva, Tania. 2006. The Changing Languages of Europe. Oxford: Oxford University Press. 
Heine, Bernd \& Kuteva, Tania. 2007. The Genesis of Grammar: A Reconstruction. Oxford: Oxford University Press.

Heine, Bernd \& Claudi, Ulrike \& Hünnemeyer, Friederike. 1991a. From cognition to grammar: Evidence from African languages. In Closs Traugott, Elizabeth \& Heine Bernd (eds.), Approaches to Grammaticalization, 149-187. Amsterdam-Philadelphia: John Benjamins.

Heine, Bernd \& Claudi, Ulrike \& Hünnemeyer, Friederike. 1991b. Grammaticalization: a Conceptual Framework. Chicago: University of Chicago Press.

Heine, Bernd \& Reh, Mechthild. 1984. Grammaticalization and Reanalysis in African Languages. Hamburg: Helmut Budke Verlag.

Heine, Bernd \& Narrog, Heiko (eds.). 2011. Introduction. In Heine, Bernd \& Narrog, Heiko (eds.), The Oxford Handbook of Grammaticalization. Oxford: Oxford University Press.

Holes, Clive. 2004. Modern Arabic: Structures, Functions and Varieties. Revised Edition. Washington: Georgetown University Press.

Hopper, Paul J. 1991. On Some Principles of Grammaticalization. In Closs Traugott, Elizabeth \& Heine, Bernd (eds.), Approaches to Grammaticalization. Vol. 1, 17-35. Amsterdam: John Benjamins.

Hopper, Paul J. 1996. Some Recent Trends in Grammaticalization. Annual Review of Anthropology 25(1). $217-$ 236.

Hopper, Paul J. \& Traugott, Elizabeth Closs. 2003. Grammaticalization. 2nd ed. Cambridge: Cambridge University Press.

Huddleston, Rodney \& Pullum, Geoffrey. 2002. The Cambridge Grammar of the English Language. Cambridge: Cambridge University Press.

Janda, Richard D. 2001. Beyond "pathways" and "unidirectionality": On the Discontinuity of Transmission and the Counterability of Grammaticalization. Language Sciences 23. 265-340.

Jóhannsdóttir, Kristín M. 2007. The Posture Verb Progressive in Icelandic. Proceedings of Sinn und Bedeutung, vol. 11: 361-374. Retrieved from http://parles.upf.edu/llocs/glif/pub/sub11.

Kinberg, Naphtali. 2001. Studies in the Linguistic Structure of Classical Arabic, 153-182 Leiden: Brill.

Klein, Wolfgang. 1994. Time in Language. London: Routledge.

Kuryłowicz, Jerzy. 1965. The Evolution of Grammatical Categories. Diogenes 51. 55-71. (Reprinted in: Esquisses linguistiques II. Munich: Wilhelm Fink Verlag, 38-54, 1975.)

Kuteva, Tania. 1999. On sit/stand/lie Auxiliation. Linguistics 37. 191-213.

Kuteva, Tania. 2001. Auxiliation: An Enquiry into the Nature of Grammaticalization. Oxford: Oxford University Press.

Lakoff, George. 1970. Irregularity in Syntax. New York: Holt, Reinhart-Winston.

Lakoff, George \& Johnson, Mark. 1980. Metaphors We Live By. Chicago: University of Chicago Press.

Lehmann, Christian. 1992. Word Order Change by Grammaticalization. In Gerritsen, Marinel \& Stein Dieter (eds.), Internal and External Factors in Syntactic Change, 395-416. Berlin-NewYork: Mouton de Gruyter.

Lehmann, Christian. 2004. Theory and Method in Grammaticalization. Zeitschrift für Germanische Linguistik 32(2). 152-187.

Lemmens, Maarten. 2002. The Semantic Network of Dutch zitten, staan, and liggen. In Newman, John (ed.), The Linguistics of Sitting, Standing, and Lying, 103-139. Amsterdam-Philadelphia: John Benjamins.

Lemmens, Maarten. 2004. Metaphor, Image Schema and Grammaticalisation. A Cognitive Lexical-Semantic Study. Journée d'Etudes. Grammar and figures of speech, Paris. http://stl.recherche.univ-lille3.fr/sitespersonnels/lemmens/abstracts/abstrengposdiachr.PDF.

Lemmens, Maarten. 2005. Aspectual Posture Verb Constructions in Dutch. Journal of Germanic Linguistics 17(3). 183-217.

Lemmens, Maarten. 2006. Caused Posture: Experiential Patterns Emerging from Corpus Research. In Gries, Stefan \& Stefanowitsch, Anatol (eds.), Corpora in Cognitive Linguistics: Corpus-Based Approaches to Syntax and Lexis, 261-296. Berlin-New York: Mouton de Gruyter.

Lemmens, Maarten \& Perrez, Julien. 2010. On the Use of Posture Verbs by French-speaking Learners of Dutch: A Corpus-based Study. Cognitive Linguistics 21(2). 315-347.

Levin, Beth \& Rappaport Hovav, Malka. 1995. Unaccusativity at the Syntax-Lexical Semantics Interface. Cambridge MA: The MIT Press.

Lichtenberk, Frantisek. 2002. Posture verbs in Oceanic. In Newman, John (ed.), The Linguistics of Sitting, Standing, and Lying, 269-314. Amsterdam-Philadelphia: John Benjamins. 
Meillet, Antoine. 1912. L'évolution des formes grammaticales. In Champion, Édouard (ed.), Linguistique historique et linguistique générale, 130-148. Paris: Librairie Ancienne Honoré Champion.

Mitchell, Terence F. 1952. The active participle in an Arabic dialect of Cyrenaica. Bulletin of the School of Oriental Studies 14. 11-33.

Mughazy, Mustafa. 2005. Rethinking lexical aspect in Egyptian Arabic. In Alhawary, Mohammad (ed.), Perspectives on Arabic Linguistics XVII-XVIII: Papers from the Seventeenth and Eighteenth Annual Symposia on Arabic Linguistics, 133-172. Oklahoma: John Benjamins.

Newman, John. 2001. A Corpus-based Study of the Figure and Ground in Sitting, Standing, and Lying Constructions. Studia Anglica Posnaniensia 36. 203-216.

Newman, John. 2002. A Crosslinguistic Overview of the Posture Verbs 'sit', 'stand', and 'lie'. In Newman, John (ed.), The Linguistics of Sitting, Standing, and Lying, 1-24. Amsterdam-Philadelphia: John Benjamins.

Newman, John \& Yamaguchi, Toshiko. 2002. Action and state interpretations of 'sit' in Japanese and English. In Newman, John (ed.), The Linguistics of Sitting, Standing, and Lying, 43-59. Amsterdam-Philadelphia: John Benjamins.

Newman, John \& Rice, Susan. 2004. Patterns of Usage for English sit, stand, and lie: A Cognitively-inspired Exploration in Corpus Linguistics. Cognitive Linguistics 15. 351-396.

Newman, John. 2009. English Posture Verbs: An Experientially Grounded Approach. Annual Review of Cognitive Linguistics 7. 30-58.

Newmeyer, Frederick. 1998. Language Form and Language Function. Cambridge, MA: MIT Press.

Newmeyer, Frederick. 2001. Deconstructing grammaticalization. Language Sciences 23. 187-229.

Norde, Muriel. 2001. Deflexion as a Counterdirectional Factor in Grammatical Change. Language Sciences 23(23). $231-264$.

Norde, Muriel. 2009. Degrammaticalization. Oxford: Oxford University Press.

Platzack, Christer. 1979. The Semantic Interpretation of Aspect and Aktionsarten: A Study of Internal Time Reference in Swedish. Dordrecht: Foris.

Ramat, Paolo. 1992. Thoughts on Degrammaticalization. Linguistics 30. 549-560.

Rothstein, Susan. 2004. Structuring Events. Oxford: Blackwell Publishing.

Ryding, Karin C. 2005. A Reference Grammar of Modern Standard Arabic. Cambridge: Cambridge University Press.

Schönefeld, Doris. 2006. From Conceptualization to Linguistic Expression: Where Languages Diversify. In Gries, Stefan \& Stefanowitsch, Anatol (eds.), Corpora in Cognitive Linguistics. Corpus-Based Approaches to Syntax and Lexis, 297-344. Berlin: Mouton de Gruyter.

Smith, Carlota S. 1983. A Theory of Aspectual Choice. Language 59. 479-501.

Smith, Carlota S. 1997. The Parameter of Aspect. Second Edition. Dordrecht: Kluwer Academic Publishers.

Smith, Andrew D. M. \& Trousdale, Graeme \& Waltereit, Richard. 2015. Introduction. In Smith, Andrew \& Trousdale, Graeme \& Waltereit, Richard. New Directions in Grammaticalization Research. Amsterdam-Philadelphia: John Benjamins.

Tonne, Ingebjørg. 2007. Analyzing progressives in Norwegian. Nordic Journal of Linguistics 30(2). 185-208.

Torres Cacoullos, Rena. 2000. Grammaticalization, Synchronic Variation, and Language Contact: a Study of Spanish Progressive -ndo Constructions. Amsterdam: John Benjamins.

Traugott, Elizabeth Closs. 2005. Constructions in Grammaticalization. In Joseph, Brian \& Janda, Richard D. (eds.), The Handbook of Historical Linguistics, 624-647. Oxford: Blackwell.

Traugott, Elizabeth Closs \& Dasher, Richard B. 2002. Regularity in Semantic Change. Cambridge: Cambridge University Press.

Traugott, Elizabeth Closs \& Trousdale, Greame. 2010. Introduction. In Closs Traugott, Elizabeth \& Trousdale, Greame (eds.), Gradience, Gradualness and Grammaticalization. Amsterdam: John Benjamin.

Traugott, Elizabeth Closs \& Trousdale, Greame. 2013. Constructionalization and Constructional Changes. Oxford: Oxford University Press.

Van Valin, Robert. 2006. Some Universals of Verb Semantics. In Mairal, Ricardo \& Gil, Juana (eds.), Linguistic Universals, 155-178. Cambridge: Cambridge University Press.

Vendler, Zeno. 1967. Linguistics in Philosophy. Ithaca, NY: Cornell University Press. 
Appendix 1: The transcription symbols

\begin{tabular}{|c|c|c|c|c|c|c|c|c|c|c|c|}
\hline 离 & $\begin{array}{l}\tilde{\Xi} \\
\text { Z̃ }\end{array}$ & $\begin{array}{l}\vec{\delta} \\
\text { 良 }\end{array}$ & 离 & $\begin{array}{l}\mathscr{\Xi} \\
\text { Z̃ }\end{array}$ & $\begin{array}{l}\overrightarrow{0} \\
\text { है } \\
\text { है }\end{array}$ & 离 & 节 & $\begin{array}{l}\overrightarrow{0} \\
\text { हे } \\
\text { ह }\end{array}$ & 离 & $\begin{array}{l}\text { E్ } \\
\text { Z }\end{array}$ & $\begin{array}{l}\overrightarrow{0} \\
\text { हे } \\
\text { ह }\end{array}$ \\
\hline 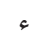 & hamza & , & $\dot{\tau}$ & $h \bar{a}$, & $h$ & ص & $s \underline{a} \bar{d}$ & $s$ & ق & $q \bar{a} f$ & $q$ \\
\hline 1 & alif & $\bar{a}$ & د & $d \bar{a} l$ & $d$ & ض & $d \bar{a} d$ & $d$ & s & $k \bar{a} f$ & $k$ \\
\hline ب & $b \bar{a}^{\prime}$ & $b$ & $\dot{~ j}$ & $\underline{d} \bar{a} l$ & $\underline{d}$ & $b$ & $t \bar{a}$, & $t$ & J & lām & $l$ \\
\hline 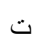 & $t \bar{a}^{\prime}$ & $t$ & $J$ & $r \bar{a}$, & $r$ & b & $z \bar{a}^{\prime}$ & $z$ & م & $\operatorname{mim}$ & $m$ \\
\hline$\dot{ث}$ & $\underline{t} \bar{a}$, & $\underline{t}$ & j & $z \bar{a} y$ & $z$ & $\varepsilon$ & 'ain & ' & ن & $n \bar{u} n$ & $n$ \\
\hline ج & ğìm & $j$ & س & $\sin$ & $s$ & $\dot{\varepsilon}$ & gain & $\bar{g}$ & 。 & $h \bar{a}$, & $h$ \\
\hline$\tau$ & $h \bar{a}$, & $h$ & ش & šin & $\check{s}$ & ف & $f \bar{a}^{\prime}$ & $f$ & & & \\
\hline \multicolumn{6}{|c|}{ Vowels } & \multicolumn{6}{|c|}{ Emirati Arabic Special Symbols } \\
\hline & & & & & & & 8 & \multicolumn{4}{|c|}{ Examples } \\
\hline 离 & 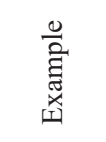 & 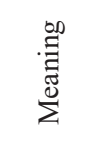 & 离 & 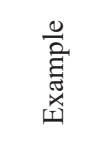 & 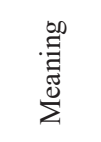 & 预 & 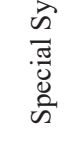 & 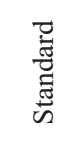 & 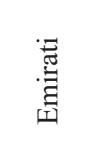 & $\begin{array}{l}\stackrel{\infty}{\Xi} \\
\stackrel{\Xi}{\Xi} \\
\stackrel{\Xi}{\Sigma}\end{array}$ & \\
\hline i & risāla & letter & $\overline{1}$ & yidīd & new & $\mathrm{j}$ & $\mathrm{y}$ & jadīè & yidīd & \multicolumn{2}{|c|}{ new } \\
\hline $\mathrm{a}$ & yiḡanni & sings & $\bar{a}$ & yālis & sitting & ḍ & z & ḍābiṭ & zāāiț & \multicolumn{2}{|c|}{ officer } \\
\hline $\mathrm{u}$ & șultān & Sultan & $\overline{\mathrm{u}}$ & maktūb & $\begin{array}{l}\text { letter, } \\
\text { written }\end{array}$ & $\mathrm{q}$ & g & waqt & wagt & \multicolumn{2}{|c|}{ time } \\
\hline & & & & & & $\mathrm{k}$ & $\mathrm{ch}$ & bākir & bāchir & \multicolumn{2}{|c|}{ tomorrow } \\
\hline
\end{tabular}


